\title{
Thermographic Patterns for Real-time Intraoperative Monitoring of Testicular Reperfusion Following Surgical Testicular Detorsion
}

\section{Patrón termográfico en tiempo real para el monitoreo de reperfusión testicular intraoperatorio en caso de torsión testicular}

\author{
Nicolas Fernandez ${ }^{1,2}$ Armando Lorenzo ${ }^{1}$ Anne-Sophie Blais ${ }^{1}$ Clyde Matava ${ }^{3}$
}

${ }^{1}$ Division of Urology, Department of Surgery, The Hospital for Sick Children (SickKids), University of Toronto, Toronto, Ontario, Canada ${ }^{2}$ Division of Urology, Department of Surgery, Hospital Universitario San Ignacio, Pontificia Universidad Javeriana, Bogotá, Colombia

${ }^{3}$ Department of Anesthesia, The Hospital for Sick Children (SickKids), University of Toronto, Toronto, Ontario, Canada

\author{
Address for correspondence Nicolas Fernandez, MD, PhD, Division of \\ Pediatric Urology, The Hospital for Sick Children, University of \\ Toronto, 555 University Ave, Toronto, ON, M5G 1X8, Canada \\ (e-mail: nicolas.fernandez@sickkids.ca; \\ fernandez.j@javeriana.edu.co).
}

\begin{abstract}
Keywords

- testicular torsion

- infrared ray

- reperfusion

Resumen

A 5-year-old patient presents to the emergency department with testicular torsion. Intraoperative sequential infrared thermographic images were registered in real-time using a FLIR One (FLIR Systems, Inc., Wilsonville, OR, US) infrared camera. The temperatures of the scrotum and the testis prior to scrotal exploration were $43.6^{\circ} \mathrm{C}$ on the affected side, and $41.7^{\circ} \mathrm{C}$ on the contralateral side. The core temperature of the patient was $36.8^{\circ} \mathrm{C}$. Immediately after the tunica vaginalis had been opened and the testis had been brought out through the incision, the temperature of the testicle was $31.5^{\circ} \mathrm{C}$. After 30 seconds of being detorted, the temperature increased to $34.3^{\circ} \mathrm{C}$. The use of intraoperative infrared thermographic imaging helps to detect discrete changes in testicular temperature, which suggests it may be useful to objectively assess reperfusion. Future studies will require more patients to correlate postoperative blood flow to the injured testis as well as volume changes after surgery to see if the intraoperative thermography findings can be used as a predictive tool for postoperative outcomes.

Paciente de 5 años de edad con historia de 8 horas de torsión testicular es llevado a cirugía. Se realiza registro imaginonlógico termográfico seriado en tiempo real del momento en que se realiza la destorsión utilizando una cámara infrarroja FLIR One. La temperatura escrotal previa a la cirgía era de $43,6^{\circ} \mathrm{C}$ del lado afectado y $41,7^{\circ} \mathrm{C}$ del lado sano. La temperatura corporal del paciente era de $36,8^{\circ} \mathrm{C}$. Inmediatemente el testiculo fue extraído y previo a la destorsión, la temperatura era de $31,5^{\circ} \mathrm{C}$. A los 30 segundos de
\end{abstract}

received December 19, 2017 accepted March 9, 2018 published online May 29, 2018
DOI https://doi.org/ 10.1055/s-0038-1656559. ISSN 0120-789X. eISSN 2027-0119.
Copyright $\odot$ 2018, Sociedad Colombiana License terms de Urología. Publicado por Thieme Revinter Publicações Ltda., Rio de Janeiro, Brazil. Todos los derechos reservados. 
Palabras clave

- torsión testicular

- rayo infrarrojo

- reperfusión la destorsión la temperatura aumentó a $34,3^{\circ} \mathrm{C}$. El uso de termografía intraoperatoria permite identificar cambios discretos que se correlacionan con aumento del flujo testicular. Estudios futuros se enfocarán en establecer variables predictorias de sobrevida del parenquima testicular al igual que definir variables intraoperatorias para definir manejos quirurgicos como orquiectomia, preservación con flap de tunica vaginal entre otras.

\section{Introduction}

Testicular torsion (TT) is a urological emergency that requires prompt surgical exploration. It presents in 1 out of 4,000 males younger than 25 years old. ${ }^{1}$ Preoperative testicular blood flow is assessed with Doppler ultrasound with a $63.6-100 \%$ sensitivity and $97-100 \%$ specificity. ${ }^{2}$ It is well established that the survival rate of the testicular parenchyma increases when prompt detorsion is performed. Molecular mechanisms have shown that reperfusion after surgical detorsion has a negative impact on the testicular parenchyma. ${ }^{3}$ Current management continues to be surgical intervention with a subjective assessment of parenchymal reperfusion to decide whether or not the testicle is salvageable. ${ }^{4}$ Intraparenchymal monitoring of testicular pressures has also shown how complex the reperfusion process can be after detorsion and the development of a compartment syndrome. ${ }^{4-6}$ This intraoperative method is invasive and technically complex, which makes it not accessible and not reproducible in each and every case. To date, there is no objective method to assess testicular reperfusion that can be used for intraoperative decision making. In the present study, we present a case in which the use of infrared thermographic imaging assisted us in identifying the reperfusion of a testicle after an 8-hour torsion with no blood flow indicated by a preoperative Doppler ultrasound.

\section{Case Presentation}

A 5-year-old boy presented to the emergency department with an 8-hour history of acute onset of left testicular pain. Following the clinical assessment, there was a high suspicion of testicular torsion. An immediate Doppler ultrasonography revealed the absence of parenchymal flow to the left testicle (-Fig. 1). The patient was brought to the operating room for scrotal exploration under general anesthesia. The intraoperative findings confirmed the presence of testicular torsion with an ischemic testicle. Intraoperatively, sequential thermographic infrared images were taken using a FLIR One (FLIR Systems, Inc., Wilsonville, OR, US) infrared camera to register in real-time the temperatures of the scrotum and the testis. Prior to being prepped, the scrotal temperature on the unheated affected side was $43.6^{\circ} \mathrm{C}$, and $41.7^{\circ} \mathrm{C}$ on the right side (-Fig. 2). The core temperature of the patient was $36.8^{\circ} \mathrm{C}$. Immediately after the tunica vaginalis had been opened and the testis had been brought out through the incision, the temperature of the testicle was $31.5^{\circ} \mathrm{C}$. After 30 seconds of being detorted, an increase in temperature to $34.3^{\circ} \mathrm{C}$ was detected ( $\mathbf{F i g . ~} \mathbf{2}$ ). The temperature of the testicle remained above $36.2^{\circ} \mathrm{C}$ after one minute of reperfusion. A tunica vaginalis flap was used after an incision had been made on the albuginea (-Fig. 2 ).

\section{Discussion}

The management of testicular torsion has remained unchanged for many decades. To date, the intraoperative decision to preserve or remove the testicle remains subjective. ${ }^{4}$ Our results present a novel technology that helps to make this decision more objective. It also adds information on how to interpret the reperfusion phenomenon intraoperatively using thermography. The delta variation in temperature $\left(\frac{\text { Torsed Temperature-Detorsed Temperature }}{\text { Final Temperature }}\right)$ showed a delta of 0.77 . Hypothetically, future studies can be used to reach a threshold delta to define which testicles have a better chance of being preserved. The use of infrared technology has been applied to help diagnose torsion prior to surgical exploration. ${ }^{1,7}$ Nonetheless, these prior studies have assessed a transdermal delta analysis of oxygen saturation but have not assessed intraoperative changes to estimate testicular perfusion. Our instrument uses a different technology that, through infrared imaging, captures the surface temperature

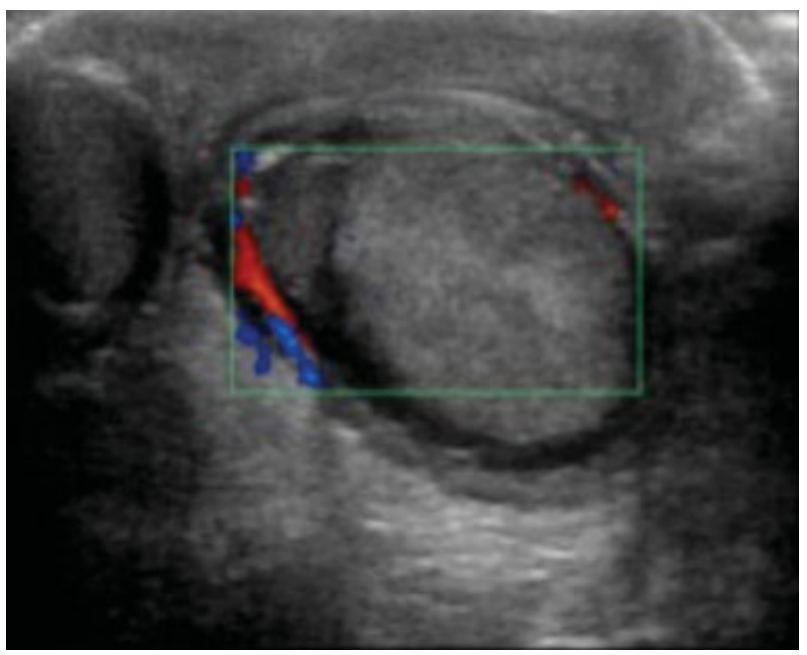

Fig. 1 Preoperative Color Doppler image of left testicle. No flow to the parenchyma. 

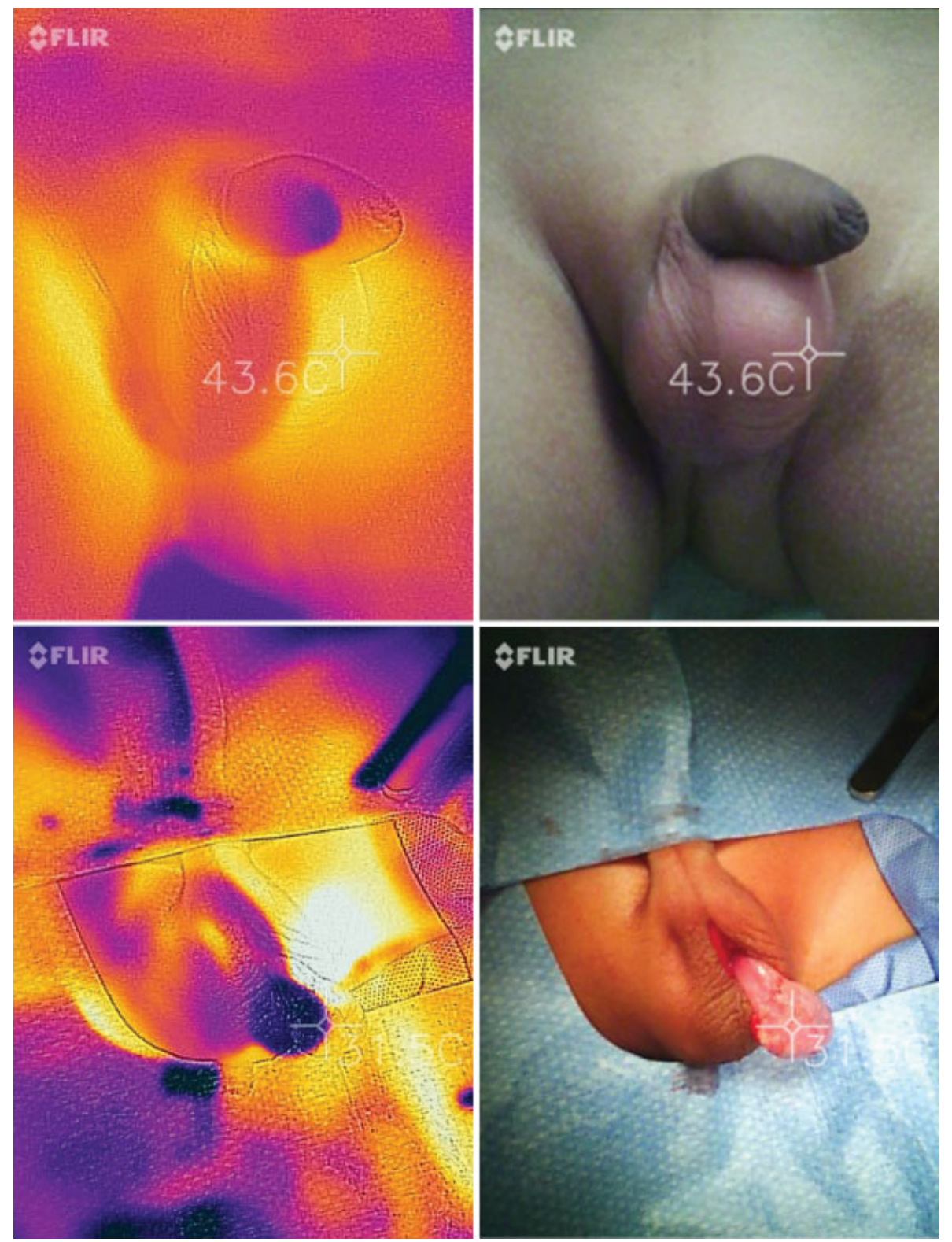

Fig. 2 Sequential images with infrared camera showing the changes in temperature throughout the scrotal exploration and testicular detorsion. (A) Image prior to prepping the patient with a temperature of $43.6^{\circ} \mathrm{C}$ on the left side and $41.7^{\circ} \mathrm{C}$ on the right hemiscrotum. (B) Immediately after the testis had been brought out through the incision, the temperature was $31.5^{\circ} \mathrm{C}$. (C) Thirty seconds after detorsion, the temperature increased to $34.3^{\circ} \mathrm{C}$. (D) One minute after reperfusion, the temperature remained above $36.2^{\circ} \mathrm{C}$.

and reconstructs it as a digital image. Changes in tissue temperature have presented a good correlation with organ perfusion. ${ }^{8,9}$ For that reason and based on our case results, the use of real-time thermography using infrared imaging is a promising technology that should be used in future studies to correlate them with postoperative outcomes. In the future, a better decision to more objectively preserve a testicle combined with a decompresive operation and possible medical management to reduce the harm of reactive oxygen specimens may offer a new standard of treatment for patients with testicular torsion.

We acknowledge that the present study is a case report without a long-term follow-up. Nonetheless, it clearly reflects the potential widespread benefit of using this technology as an intraoperative tool to decide whether or not an organ should be preserved, and to estimate the potential of recovery.

A limiting factor might be the effect that this surgical technique can have on the temperature of the tissue. For instance, prepping the patient reduces skin temperature due to the evaporation of the alcohol component of the prepping solution. Also, touching the tissue may leave thermal fingerprints of the surgeon on the tissue, causing false readings. For our case, we did take those factors into account, and this is why the preoperative thermal reading was made prior to prepping the patient, and the handling of the testicle was performed only 

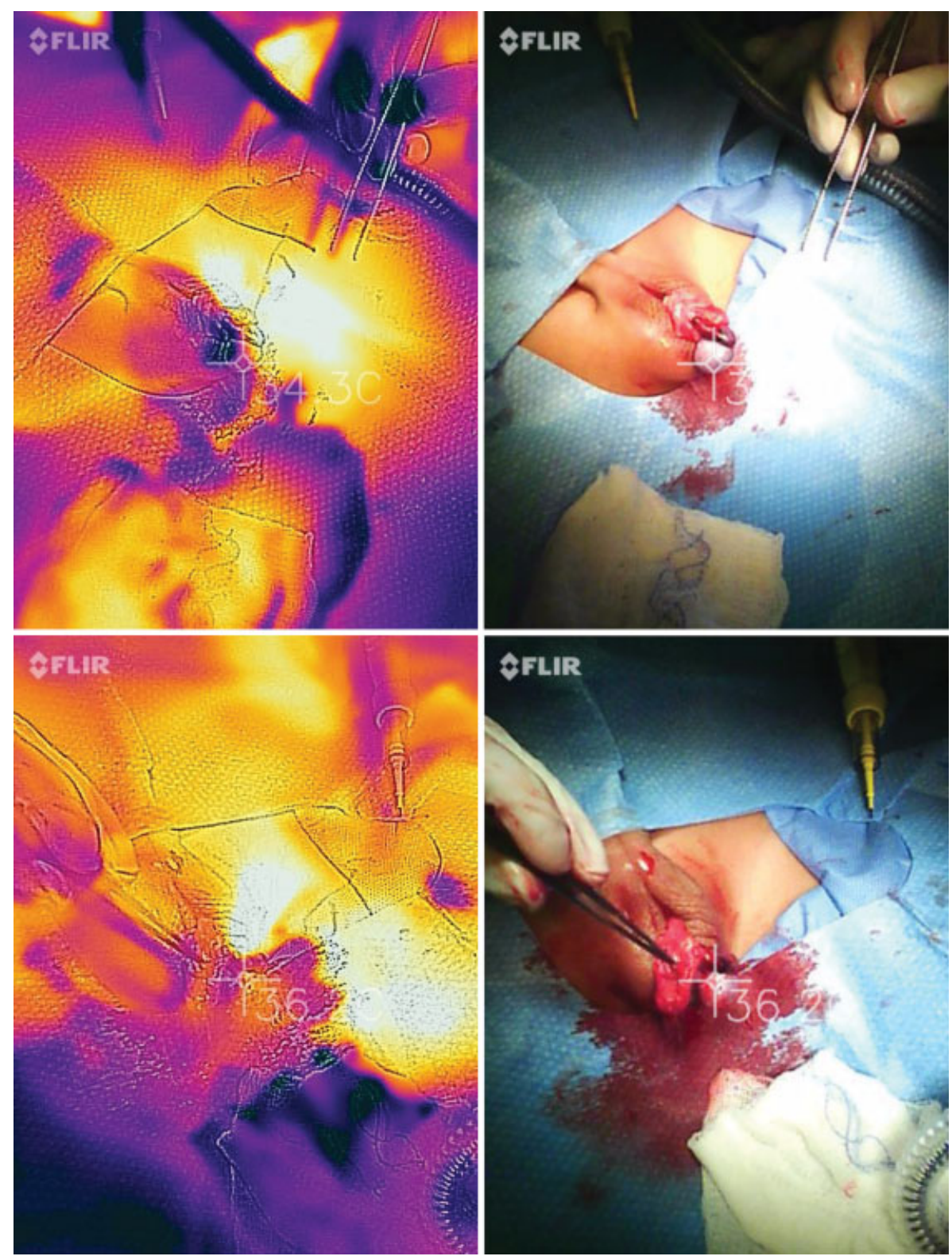

Fig. 2 (Continued)

with instruments. In fact, the temperature trend of the testicle confirms that it was not affected by the surgeon. Images not shown demonstrate that the temperature of the hand of the surgeon was below the readings we had on the testicle, which means that the temperature was not affected by the surgeon.

\section{Conclusion}

The use of intraoperative infrared imaging helps to detect discrete changes in testicular temperature, which suggests that it may be useful to objectively assess reperfusion. Future studies will require more patients to correlate postoperative blood flow to the injured testis as well as volume changes after surgery to see if intraoperative thermography findings can be used as a predictive tool for postoperative outcomes.

\section{References}

1 Schlomer BJ, Keays MA, Grimsby GM, et al. Transscrotal Near Infrared Spectroscopy as a Diagnostic Test for Testis Torsion in Pediatric Acute Scrotum: A Prospective Comparison to Gold Standard Diagnostic Test Study. J Urol 2017;198(03):694-701. Doi: 10.1016/j.juro.2017.03.134 [Internet]

2 Baker LA, Sigman D, Mathews RI, Benson J, Docimo SG. An analysis of clinical outcomes using color doppler testicular ultrasound for testicular torsion. Pediatrics 2000;105(3 Pt 1):604-607

3 Shamsi-Gamchi N, Razi M, Behfar M. Testicular torsion and reperfusion: evidences for biochemical and molecular alterations. Cell Stress Chaperones 2018;23(03):429-439

4 Figueroa V, Pippi Salle JL, Braga LHP, et al. Comparative analysis of detorsion alone versus detorsion and tunica albuginea decompression (fasciotomy) with tunica vaginalis flap coverage in the surgical management of prolonged testicular ischemia. J Urol 2012;188(4, Suppl)1417-1422. Doi: 10.1016/j.juro. 2012.02.017 
5 Kutikov A, Casale P, White MA, et al. Testicular compartment syndrome: a new approach to conceptualizing and managing testicular torsion. Urology 2008;72(04):786-789

6 Watson MJ, Bartkowski DP, Nelson NC. Intracompartmental pressure as a predictor of intratesticular blood flow: a rat model. J Urol 2015;193(06):2062-2067

7 Shadgan B, Fareghi M, Stothers L, Macnab A, Kajbafzadeh AM. Diagnosis of testicular torsion using near infrared spectroscopy: A novel diagnostic approach. Can Urol Assoc J 2014;8(3-4): E249-E252

8 Gorbach A, Simonton D, Hale DA, Swanson SJ, Kirk AD. Objective, real-time, intraoperative assessment of renal perfusion using infrared imaging. Am J Transplant 2003;3(08):988-993

9 Haluzan D, Davila S, Antabak A, et al. Thermal changes during healing of distal radius fractures-Preliminary findings. Injury 2015;46(Suppl 6):S103-S106 